\title{
Further notes on the natural history of the South American pepper frog, Leptodactylus labyrinthicus (Spix, 1824) (Anura, Leptodactylidae)
}

\author{
Silva, WR.* and Giaretta, AA. \\ Laboratório de Taxonomia, Sistemática e Ecologia Comportamental de Anuros Neotropicais, Instituto de Biologia, \\ Campus Umuarama, Universidade Federal de Uberlândia - UFU, \\ Rua Ceará, sn, Bloco 2D, CEP 38400-902, Uberlândia, MG, Brazil \\ *e-mail: wagnerdrigues@yahoo.com.br
}

Received June 7, 2006 - Accepted November 9, 2006 - Distributed May 31, 2008

(With 1 figure)

\begin{abstract}
Leptodactylus labyrinthicus tadpoles reach a large size in the nest through consumption of trophic eggs. We previously suggested that the trophic eggs are laid just after amplexus has finished, but our new data do not support this hypothesis. We also present further details on the natural history of the species with regard to breeding activity, spawning site, retreats and the ability of tadpoles in preying upon fully-growth heterospecific tadpoles. We also show that the tadpoles are mainly nocturnal and take diurnal refuges. We collected the data in Brazil in three localities within the Cerrado Biome. We examined burrows used by L. labyrinthicus males, verified if females still contained mature eggs just after released from amplexus, and tested the ability of tadpoles in preying fully-growth heterospecific tadpoles. Field observations and experiments were conducted on tadpole activity time, hiding behaviour and level of susceptibility to predation by the bird leaf-scrapers in four sheltering situations. Reproduction could start before the first rains; this may be advantageous by allowing the tadpoles to exploit eggs of other frogs. We found one floating nest built in a temporary pool. The nest of the species is normally circumscribed in an excavated basin beside the water body. Adult males were found during the day with their head-out of the entrance of underwater burrows, which were perforations through dense root mats beside calling/spawning sites. Probably, these burrows in permanently water-filled soil are actively excavated by males. Females released all their eggs during the amplexus, so trophic eggs are not produced by the currently-accepted mechanism. Fully-grown heterospecific tadpoles were not preyed upon by L. labyrinthicus tadpoles, which can prey only slow-moving newly hatched ones. Field tadpoles took shelter under mud/dead leaves during daylight and became exposed on the bottom at night. Free-ranging leaf-scrapers removed dead leaves from a pool with their beaks and preyed upon tadpoles. In the experiments, the tadpoles sheltered under gravel/leaves during daylight, but they were exposed at night. Leaf-scrapers ate all exposed tadpoles, but no tadpole of the gravel/leaves trays was consumed. Hence the nocturnal habits and use of diurnal refuges may protect the tadpoles from visual predators, such as the leaf-scrapers.
\end{abstract}

Keywords: Leptodactylus pentadactylus group, reproduction, retreats, trophic eggs, tadpoles.

\section{Notas complementares sobre a história natural da rã-pimenta sul-americana, Leptodactylus labyrinthicus (Anura, Leptodactylidae)}

\section{Resumo}

Girinos de L. labyrinthicus crescem parcialmente no ninho consumindo ovos tróficos. Sugerimos anteriormente que os ovos tróficos seriam postos logo após o amplexo, porém nossos novos dados não corroboram esta hipótese. Apresentamos também mais detalhes da história natural da espécie relacionados à estação reprodutiva, local de desova, abrigos e capacidade dos girinos em predar girinos heteroespecíficos plenamente desenvolvidos. Demonstramos ainda que os girinos são noturnos e se utilizam de refúgios diurnos. Coletamos os dados no Brasil em três locais no Bioma Cerrado. Determinamos o formato e dimensões de buracos utilizados por machos, verificamos se fêmeas liberadas do amplexo ainda portavam óvulos maduros e testamos a capacidade dos girinos em predar girinos heteroespecíficos plenamente desenvolvidos. Realizamos observações naturalísticas e experimentais com girinos para descrever o horário de atividade, comportamento de refúgio e grau de suscetibilidade à predação pela ave sabiá-poca em diferentes tipos de substratos. Desovas podiam ocorrer antes das primeiras chuvas, possibilitando aos girinos explorar ovos de outros anuros no meio da estação chuvosa. Encontramos um ninho construído na superfície da água de uma poça temporária. Os ninhos da espécie geralmente são circunscritos em bacias escavadas às margens do corpo d'água. Machos adultos foram encontrados durante o dia em buracos subaquáticos, os quais eram perfurações adjacentes aos sítios de vocali- 
zação/desova. Provavelmente, esses buracos em solos encharcados são ativamente escavados pelos machos. As fêmeas liberam todos os óvulos durante o amplexo, portanto, os ovos tróficos não são produzidos pelo mecanismo aceito presentemente. Os girinos oferecidos nos testes não foram consumidos pelos girinos de L. labyrinthicus, os quais conseguem predar apenas recém-eclodidos. No campo, os girinos se refugiavam entre o lodo ou folhas mortas durante o dia, porém ficavam expostos sobre o fundo à noite. Dois sabiás-poca removeram folhas de uma poça e predaram girinos. Nos experimentos, os girinos se escondiam entre o cascalho/folhas no período diurno, mas tornavam-se expostos à noite. As aves predaram todos os girinos expostos, mas nenhum girino nos recipientes com cascalho/folhas foi consumido. Portanto, o hábito noturno e a utilização de refúgios diurnos devem proteger os girinos da espécie contra predadores visualmente orientados, como as aves.

Palavras-chave: grupo de Leptodactylus pentadactylus, reprodução, abrigos, ovos tróficos, girinos.

\section{Introduction}

Several species of Leptodactylus of the L. pentadactylus group (sensu Heyer, 1979; 2005) build their foam nests on land in excavated basins and have oophagous tadpoles (Muedeking and Heyer, 1976; Cardoso and Sazima, 1977; Hero and Galatti, 1990; Hödl, 1990; Gascon, 1991; Aichinger, 1992; Gibson and Buley, 2004; Prado et al., 2005; Silva et al., 2005). Leptodactylus labyrinthicus tadpoles reach a large size within the nest through consumption of trophic eggs, but complete their metamorphosis in water, where they prey upon anuran eggs and tadpoles or feed on carrion (Cardoso and Sazima, 1977; Agostinho et al., 2002; Prado et al., 2005; Shepard and Caldwell, 2005; Silva et al., 2005; Silva and Muniz, 2005; Zina and Haddad, 2005).

Prado et al. (2004) did not find differences in the morphology and staining pattern between ovarian and developing eggs in L. labyrinthicus. In a previous study (Silva et al., 2005), we suggested that the trophic eggs of this species are produced by females releasing eggs immediately after the male finished amplexus and left the foam nest. However, herein we present data that do not support this hypothesis. We also present new data on the natural history of this species with regard to seasonality in reproduction, nest building site, diurnal retreats and the ability of the tadpoles in preying upon fully-grown tadpoles of other species. Furthermore, we describe that the tadpoles are mainly nocturnal and take shelter during the day probably to avoid visually-orientated predators.

\section{Material and Methods}

We carried out the present study (2003-5) in the Brazilian municipalities of Uberlândia $\left(18^{\circ} 55^{\prime} \mathrm{S}\right.$ and $48^{\circ} 17^{\prime} \mathrm{W}$ ), Araguari (18 $29^{\prime}$ 'S and $48^{\circ} 30^{\prime} \mathrm{W}$ )(Minas Gerais State), and Caldas Novas ( $17^{\circ} 43^{\prime} \mathrm{S}$ and $48^{\circ} 40^{\prime} \mathrm{W}$ ) (Goiás State). All localities are in the Cerrado Biome (Central South America savanna) with a wet/hot season from September to April, a dry/mild season from May to August, and with an annual mean precipitation of around 1,500 mm (Oliveira and Marquis, 2002; Giaretta and Kokubum, 2004).

We looked for wintering (June 2003) tadpoles in water bodies $(n=3)$ often used for reproduction through stovepipe (a metal ring of $45 \mathrm{~cm}$ height and $56 \mathrm{~cm}$ diameter) sampling (Shaffer et al., 1994) and with the aid of a sieve ( $3 \mathrm{~mm}$ mesh). We examined underwater burrows used by adults by extending an arm into them to determine their shape and estimate their length/diameter. We removed rotting grass and superficial mud from drying ponds $(n=3)$ in winter months to look for buried transformed individuals. A clustering behavior of the tadpoles observed in recently dried pools was described.

To test if females still contained mature eggs just after release from amplexus (Silva et al., 2005), we dissected two of them preserved just after the males had left the foam nests $(<30$ seconds). The egg-clutch of one of these females was examined five days later in order to determine the proportion of eggs and tadpoles. On another occasion, we kept a just-released (amplexus) nesting female under observation until she left the foam nest.

Because we found large-sized tadpoles in an old aged egg clutch, we suspected that tadpoles could complete metamorphosis within the basin. To test this hypothesis we kept individual one-week-old egg clutches $(\mathrm{n}=10)$ in containers ( $3 \mathrm{~L}$; glass or clay) with 1-2 L of dechlorinated tap water in outdoor experimental conditions. These nests were covered with a fine nylon mesh and kept in a partially-shaded place under ambient temperature $\left(25-29^{\circ} \mathrm{C}\right)$ and photoperiod. We checked for tadpole size twice a week for at least three months. The references to larval stages follow Gosner (1960).

Leptodactylus labyrinthicus tadpoles are known to prey newly-hatched tadpoles of Physalaemus cuvieri Fitzinger, 1826 (Cardoso and Sazima, 1977). We offered P. cuvieri (19-27 mm TL; stage 25) and Pseudopaludicola sp. (17-25 mm TL; stage 25) tadpoles to L. labyrinthicus tadpoles (47-55 mm; stage 29-36) to test their ability of preying upon fully-grown tadpoles of other species. These prey tadpoles were collected from water bodies where they occur syntopically with L. labyrinthicus. We offered one prey for each L. labyrinthicus tadpole in circular containers $(1 \mathrm{~L})$ with $0.5 \mathrm{~L}$ of water $\left(21-23^{\circ} \mathrm{C}\right)$. We conducted 14 replications throughout one night for each prey species. Prior to prey presentation, L. labyrinthicus tadpoles were kept unfed for five days.

Field observations and experiments were conducted on tadpole activity time, hiding behaviour and level of susceptibility to predation by free-ranging leaf-scrapers (Turdus amaurochalinos Cabanis, 1851, Passeriformes) (Muniz and Silva, 2005) in four different sheltering sit- 
uations. A total of 160 tadpoles (28-43 mm TL; $\mathrm{n}=3$ clutches) was used. We placed groups of 10 tadpoles in white opaque plastic trays ( $45 \times 25 \times 8 \mathrm{~cm} ; 3 \mathrm{~L}$ water) either without any substrate or with dark-gray gravel and dead leaves (similar to the pools from which they were collected). The first test was to determine the diel pattern of activity and hiding behavior. Two groups of 10 tadpoles were arranged in two trays. In one half of each tray, we placed gravel/leaves, and left the other half without any substrate. Food (a small piece of carrion) was placed on the white-bottomed side of these trays. We took note of the number of tadpoles in each side of the trays during a 24 hours period (1-3 hours intervals).

In a second experiment ( 80 tadpoles), we assessed the efficiency of gravel/leaves to protect tadpoles from free-ranging leaf-scrapers. We distributed two sets of 10 tadpoles in two trays without any substrate (exposed tadpoles), and two sets in trays with gravel/leaves. In a third experiment (60 tadpoles), we submitted groups of 10 tadpoles to three conditions in three trays: 1) Gravel/ leaves, 2) Gravel, and 3) Leaves to determine which of these would provide greater protection against birds. During the tests, we observed the birds' behavior (at least two individuals) with binoculars from about $13 \mathrm{~m}$. The exposures to the predator were carried out in the morning (7:00 AM) and afternoon (5:00 PM). In each experiment, the trays with the different sheltering conditions were exposed simultaneously in the field for 30 minutes.

\section{Results and Discussion}

\subsection{Reproductive activity and oviposition sites}

From August/September to February, males called regularly during the night, but on rare occasions ( $n=4$ times; September and November) advertisement calls were heard during sunny hours (10:00 AM-1:00 PM). In contrast to our new data, previous studies described the calling period of L. labyrinthicus as being strictly nocturnal (Silva et al., 2005; Zina and Haddad, 2005).

In 2004, rains started in mid-October, but calling activity and egg clutches $(n=6)$ occurred from early September. The long time (up to 25 days) the tadpoles can remain in the nest on their trophic egg-based diet (Prado et al., 2005; Silva et al., 2005) may favor those individuals reproducing before the first rains, because their tadpoles can exploit the eggs of other frog species (e.g., Physalaemus spp.) laid just after the first heavy rains (personal observation).

We found one floating egg clutch built amidst a dense tuff of emerging grass-like plants in a small $\left(1.5 \mathrm{~m}^{2}\right.$; $60 \mathrm{~cm}$ deep) temporary pool. The foam nest of the species is normally circumscribed in an excavated basin beside the water body (Silva et al., 2005; Zina and Haddad, 2005). Rarely and alternatively, foam nests were found on dry land (Silva et al., 2005) and on the top of water (Eterovick and Sazima, 2000; present study).

Mid-winter (June) stovepipe sampling produced no L. labyrinthicus tadpoles ( $\mathrm{n}=3$ water bodies, 15 sam- ples). Regarding the possible protection the basin may offer to eggs/early tadpoles against cannibal tadpoles (Silva et al., 2005), deposition of the foam nest directly on the water at the beginning of the reproductive season would not bring greater risks from conspecifics, as tadpoles of this species do not overwinter.

\subsection{Retreats}

Adult males $(n=5)$ were found with their head out of the entrance of water-filled burrows during the day. These burrows were perforations through dense root mats beside (30-250 cm distance) calling/spawning sites. Males often took refuge diving into these burrows when observers approached (ca. $4 \mathrm{~m} ; \mathrm{n}=5$ occasions). Underwater burrows $(\mathrm{n}=5)$ had a diameter of around $120 \mathrm{~mm}$ and were about $30-80 \mathrm{~cm}$ in length (up to $50 \mathrm{~cm}$ under water). They were either directed straight towards the bottom $(n=2)$ or curved parallel to the surface $(n=3)$. We recovered individual males from these burrows when extending an arm into them. Three burrows examined in the winter months were not occupied. Tozetti and Toledo (2005) described burrow utilization by both adult males and females L. labyrinthicus and suggested that such burrows are constructed by mammals. We agree that those burrows far from the water could be dug by mammals, but suggest that those in swamps (highly humid soil) may have been actively excavated by males. Probably, males establish territories around proper egglaying sites and use these burrows as diurnal shelters and escape retreats during the reproductive season. Eterovick and Sazima (2004) also referred to the species as using "cavities in swampy areas". Males of L. flavopictus Lutz, 1926, another species of the L. pentadactylus group (Heyer, 1979), appear to have this burrowing behaviour as well (Bokermann, 1957).

In August (dry season 2003), after removing the dry grasses and superficial $(<10 \mathrm{~cm})$ mud of a drying pool $\left(6 \mathrm{~m}^{2}\right)$, we found three buried juveniles $(61-69 \mathrm{~mm}$ SVL). All were responsive (not dormant) to manipulation. Compact aggregates $(n=3)$ of living tadpoles (up to 37 individuals; $35-60 \mathrm{~mm}$ TL) were found hidden in crevices in soil or under garbage (pieces of clothing and plastic bags) 1-2 days after the ponds had dried out.

\subsection{Trophic egg production}

Both females collected immediately after being released from amplexus did not bear any mature egg (oocytes) in their ovaries or oviducts. After five days in the field, the egg clutch of one of these females had 111 $(5.2 \%)$ tadpoles and 2,035 trophic eggs. The female observed after being released from the amplexus remained motionless within the foam nest for 17 minutes before leaving it. Therefore, L. labyrinthicus females release all their eggs during the amplexus and the trophic eggs are not produced by a behavioural mechanism as we previously suggested (Silva et al., 2005). More detailed studies on late gametogenesis of the species (Prado et al., 2004) may point to structural differences between trophic and developing eggs. Females of L. fallax Muller, 1926 
(L. pentadactylus species group) periodically release unfertilized (trophic) eggs to feed their tadpoles (Gibson and Buley, 2004). This mechanism does not apply to L. labyrinthicus, since in our study area females of this species do not remain or periodically return to their foam nest after mating to lay fresh eggs.

\subsection{Tadpole development and behavior}

From one of the 10 clutches kept in the laboratory with no food supply other than the original trophic eggs, two tadpoles reached metamorphosis within 54 days (17-19 $\mathrm{mm}$ SVL) feeding on trophic eggs and cannibalizing dead siblings. In a second clutch, a tadpole almost reached metamorphosis $(60 \mathrm{~mm}$ TL; stage 40) after 40 days. In the remaining clutches $(n=8)$, tadpoles died after 1-3 months, the siblings not differing notably in size $(<45 \mathrm{~mm}$ TL) after this time. In September 2003, we followed (for 20 days) a clutch isolated from the main water body, which produced three large sized tadpoles (largest $=50.0 \mathrm{~mm}$ TL, stage 27); at that age time 1120 trophic eggs remained. Prado et al. (2005) also succeeded in having one tadpole metamorphosing in laboratory conditions similar to our results. Leptodactylus labyrinthicus tadpoles are opportunistic cannibals (sensu Crump, 1983; 1986), just eating already dead siblings.

In the laboratory, fully-grown tadpoles of $P$. cuvieri and Pseudopaludicola sp. were not preyed upon by L. labyrinthicus tadpoles. An important issue in reports on heterospecific tadpole predation by Leptodactylus species of the L. pentadactylus group is that tadpole consumption is restricted to slow-moving newly hatched preys (Heyer et al., 1975; Cardoso and Sazima, 1977; present study).

\subsection{Diel pattern of activity and hiding behavior}

Living L. labyrinthicus tadpoles are cryptic colored, with a dark gray back and tail. In the field, they normally took shelter under dead leaves or debris during daylight and became exposed on the bottom at night. Tadpoles were seen swarming under foam nests of other leptodactyline frogs (e.g., Physalaemus spp.) during the day ( $n=5$ observations).

In our first experiment, tadpoles sheltered under gravel/leaves during daylight (7:00 AM-6:00 PM), but they were exposed around the carrion at night, mainly between 7:00 and 11:00 PM ( $\mathrm{n}=38$ inspections) (Figure 1). Tadpoles often took shelter when illuminated by flashlights ( $n=6$ times).

In the field, free-ranging leaf-scrapers were observed removing dead leaves from the bottom of a shallow pool with their beaks and preying upon tadpoles $(n=10$; ca. $40 \mathrm{~mm} \mathrm{TL}$ ). The leaf-scrapers attempted to prey upon tadpoles in all experimental trays. The birds turned several leaves (ca. 35) of trays with gravels/leaves. In the second experiment, leaf-scrapers ate all exposed tadpoles, but no tadpole of the gravel/leaves trays was consumed. In the third experiment, tadpoles in gravel (90\%)

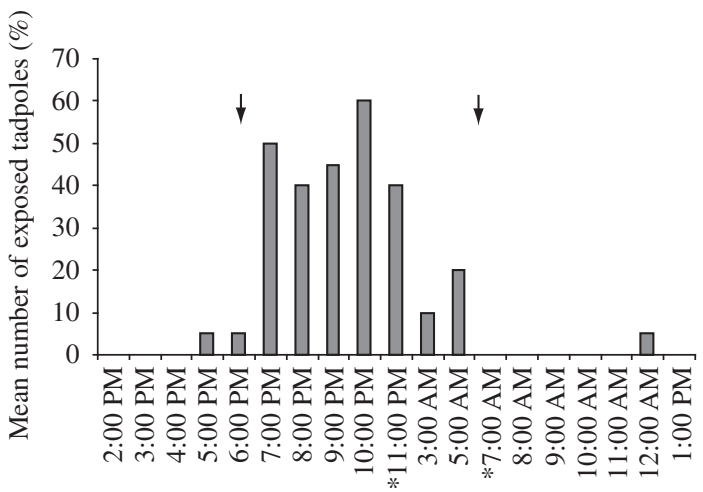

Time (hour)

Figure 1. Diel activity pattern of Leptodactylus labyrinthicus tadpoles ( $\mathrm{n}=20$ individuals; 38 visual inspections). The left and right arrows indicate sunset (6:30 PM) and sunrise (6:30 AM), respectively. * - No inspections were made between 24-2, 4, or 6 hours.

and gravel/leaves (15\%) trays were consumed. No tadpole was captured from the trays containing just leaves.

Unpalatability is a main defense of anuran larvae against predaceous teleosts (e.g., Hero et al., 2001). We have no evidence of unpalatability of L. labyrinthicus tadpoles to snakes and birds (Muniz and Silva, 2005; present study). The use of diurnal shelters (mud/leaf litter) and nocturnal habits may protect tadpoles from visual predators, such as the leaf-scrapers. As in other systems (review: Kronfeld-Schor and Dayan, 2003), these differential diel activity patterns may allow predator/prey coexistence. The kind of microhabitat used influences predation risks by determining the level of exposure of tadpoles to predators (Morin, 1986). In our experiments, the leaves (and combined gravel/leaves) appear to provide protection to tadpoles against birds by making detection and capture difficult. Besides L. labyrinthicus, tadpoles of other species use leaf litter as microhabitat refugia (Morin, 1986; Semlitsch and Reyer, 1992; Hero et al., 2001).

Acknowledgements - We are grateful to FAPEMIG, CAPES (WRS) and $\mathrm{CNPq}$ (AAG) for providing grants. Financial support from CNPq and FAPEMIG. K. G. Facure and W. R. Heyer critically read the draft.

\section{References}

AGOSTINHO, CA., FORESTI, F., LIMA, SL. and JIM, J., 2002. Reproduction and population size of Leptodactylus labyrinthicus (Anura, Leptodactylidae). Russ. J. Herpetol., vol. 9, no. 1, p. 15-20.

AICHINGER, M., 1992. Fecundity and breeding sites of an anuran community in a seasonal tropical environment. Stud. Neotrop. Fauna E., vol. 27, no. 1, p. 9-18.

BOKERMANN, WCA., 1957. Notas sobre a biologia de Leptodactylus flavopictus Lutz, 1926. Rev. Brasil. Biol., vol. 17, no. 4, p. 495-500. 
CARDOSO, AJ. and SAZIMA, I., 1977. Batracofagia na fase adulta e larvária de rã-pimenta, Leptodactylus labyrinthicus (Anura, Leptodactylidae). Cienc. Cult., vol. 29, no. 10, p. 1130-1132.

CRUMP, ML., 1983. Opportunistic cannibalism by amphibian larvae in temporary aquatic environments. Am. Nat., vol. 121, no. 2, p. 281-289.

-, 1986. Cannibalism by younger tadpoles: another hazard of metamorphosis. Copeia, vol. 1986, no. 4, p. 1007-1009.

ETEROVICK, PC. and SAZIMA, I., 2000. Description of the tadpole of Leptodactylus syphax, with a comparison of morphological and ecological characters of tadpoles and adults of the species in the L. pentadactylus group (Anura, Leptodactylidae). Amphibia-Reptilia, vol. 21, no. 3, p. 341-350.

-, 2004. Amphibians from the Serra do Cipó, Minas Gerais, Brazil. Belo Horizonte: PUC Minas. 150 p.

GASCON, C., 1991. Breeding of Leptodactylus knudseni: responses to rainfall variation. Copeia, vol. 1991, no. 1, p. $248-252$.

GIARETTA, AA. and KOKUBUM, MNC., 2004. Reproductive ecology of Leptodactylus furnarius Sazima and Bokermann, 1978, a frog that lays eggs in underground chambers (Anura: Leptodactylidae). Herpetozoa, vol. 16, no. 3, p. 115-126.

GIBSON, RC. and BULEY, KR., 2004. Maternal care and obligatory oophagy in Leptodactylus fallax: a new reproductive mode in frogs. Copeia, vol. 2004, no. 1, p. 128-135.

GOSNER, KL., 1960. A simplified table for staging anuran embryos and larvae with notes on identification. Herpetologica, vol. 16, no. 3, p. 183-190.

HERO, JM. and GALATTI, U., 1990. Characteristics distinguishing Leptodactylus pentadactylus and L. knudseni in the Central Amazon Rainforest. J. Herpetol., vol. 24, no. 2, p. 227-228.

HERO, JM., MAGNUSSON, WE., ROCHA, CFD. and CATTERALL, CP., 2001. Antipredator defenses influence the distribution of amphibian prey species in the central Amazon rain forest. Biotropica, vol. 33, no. 1, p. 131-141.

HEYER, WR., 1979. Systematic of the pentadactylus species group of the frog genus Leptodactylus (Amphibia, Anura). Smithson. Contrib. Zool., vol. 301, p. 1-43.

HEYER, WR., 2005. Variation and taxonomic clarification of the large species of the Leptodactylus pentadactylus species group (Amphibia, Leptodactylidae) from Middle America, northern South America, and Amazonia. Arq. Zool., vol. 37, no. 3, p. 269-348.

HEYER, WR., McDIARMID, RW and WEIGMANN, DL., 1975. Tadpoles, predation and pond habitats in the tropics. Biotropica, vol. 7, no. 2, p. 100-111.

HÖDL, W., 1990. Reproductive diversity in Amazonian lowland frogs. In W. Hanke (ed.). Biology and physiology of the amphibians. Fotschritte der Zoologie, Stuttgart and New York.
KRONFELD-SCHOR, N. and DAYAN, T., 2003. Partitioning of time as an ecological resource. Annu. Rev. Ecol. Evol. Syst., vol. 34, p. 153-181.

MORIN, PJ., 1986. Interactions between intraspecific competition and predation in an amphibian predator-prey system. Ecology, vol. 67, no. 3, p. 713-720.

MUEDEKING, MH. and HEYER, WR., 1976. Description of eggs and reproductive patterns of Leptodactylus pentadactylus (Amphibia, Leptodactylidae). Herpetologica, vol. 32, no. 2, p. 137-139.

MUNIZ, KPR. and SILVA, WR., 2005. Leptodactylus labyrinthicus (South American pepper frog): Predation. Herpetol. Rev., vol. 36, no. 3, p. 302-303.

OLIVEIRA, PS. and MARQUIS, RJ., 2002. The Cerrados of Brazil: ecology and natural history of a Neotropical savanna. USA: Columbia University Press. 398 p.

PRADO, CPA., ABDALLA, FC., SILVA, APZ. and ZINA, J., 2004. Late gametogenesis in Leptodactylus labyrinthicus (Anura, Leptodactylidae) and some ecological considerations. Braz. J. Morphol. Sci., vol. 21, no. 4, p. 177-184.

PRADO, CPA., TOLEDO, LF., ZINA, J. and HADDAD, CFB., 2005. Trophic eggs in the foam nests of Leptodactylus labyrinthicus (Anura, Leptodactylidae): an experimental approach. Herpetol. J., vol. 15, no. 4, p. 279-284.

SEMLITSCH, RD. and REYER, HU., 1992. Modification of anti-predator behavior in tadpoles by environmental conditions. J. Anim. Ecol., vol. 61, no. 2, p. 353-360.

SHAFFER, HB., ALFORD, RA., WOODWARD, BD., RICHARDS, SJ., ALTIG, RG. and GASCON, C., 1994, Quantitative sampling of amphibian larvae. In HEYER, WR., DONNELLY, MA., McDIARMID, RW., HAYEK, LC. and FOSTER, MS. (eds.). Measuring and monitoring biological diversity, standard methods for amphibians. Smithson. Washington, D.C: Inst. Press. p. 126-130.

SHEPARD, DB. and CALDWELL, JP., 2005. From foam to free-living: ecology of larval Leptodactylus labyrinthicus. Copeia, vol. 2005, no. 4, p. 803-811.

SILVA, WR., GIARETTA, AA. and FACURE, KG., 2005. On the natural history of the South American pepper frog, Leptodactylus labyrinthicus (Spix, 1824) (Anura, Leptodactylidae). J. Nat. Hist., vol. 39, no. 7, p. 555-566.

SILVA, WR. and MUNIZ, KPR., 2005. Leptodactylus labyrinthicus (South American pepper frog): Necrophagy. Herpetol. Rev., vol. 36, no. 3, p. 302.

TOZETTI, AM. and TOLEDO, LF., 2005. Short-term movement and retreat sites of Leptodactylus labyrinthicus (Anura, Leptodactylidae) during the breeding season: a spool-and-line tracking study. J. Herpetol., vol. 39, no. 4, p. 640-644.

ZINA, J. and HADDAD, CFB., 2005. Breeding activity and vocalizations of Leptodactylus labyrinthicus (Anura, Leptodactylidae) in the southeast of Brazil. Biota Neotrop., vol. 5 , no. 2, p. 0-10. 